\title{
"Geometric Power"
}

\author{
The Aesthetic Logic of Zellige
}

\author{
Guanghui Chen \\ Shanghai Academy of Fine Arts \\ Shanghai University \\ Shanghai, China
}

\begin{abstract}
Zellige is a specific Moroccan ceramic mosaic, normally in geometric design. It is not only the decorative feature of Islamic Moroccan buildings, but also the peak of the building decoration worldwide. Since almost all the literatures on the world history of arts and craft and of building have overlooked the art in North Africa consciously or unconsciously, the author intends to find out the origin and the aesthetic appreciation of Zellige through the field trip and research. The author realizes that the research on Zellige requires the background and difficulty analysis on the mixed culture of Islam and Morocco. For this, the author accepted professional Zellige geometric training in the institute of Zellige in Tetuan of Morocco. As the research goes further, we can take the history of European, Asian and African culture and civilization and Islamic geometric aesthetics as the cultural background for the research. Then, we can turn to specific Moroccan Islamic architecture, Madesa, and mosque as the physical background of the research. Finally, we turn back to the research of the Zellige itself. By this research idea and the analysis on the first-hand material on Morocco, the author can complete this paper through relative studies, such as historical information, religious culture, architecture art, ceramic material, comparative culture, etc.
\end{abstract}

Keywords-Zellige; Morocco; Maghrib; Islam; Mediterranean; ceramics; mosaic; architecture; geometric; arts and crafts

\section{INTRODUCTION}

Zellige is the specific ceramic mosaic in Morocco, normally in geometrical design. It is the main decoration material for the walls and floors of Madesa, the Islamic Moroccan architecture. This decoration framework is a halfmeasure to observe the Islamic doctrines to avoid image description during decorating spaces. Zellige, a French word directly transliterated from the Arabian word, refers to the mosaic by small ceramic geometrical pieces used for the decoration of the wall, fountain, floor, etc. The French word "Zellige" is adopted because there is no specific Chinese name for this special mixed decorative culture. With its own referent, both Mosaic and parquet ceramic tile can not express the small pieces patchwork with strict constraint by Islamized geometrical designs. In fact, Zellige carries many cognitive elements. Materially, it is low-fired porcelain and lead glaze; on the principle of splicing, it is a patchwork of Mediterranean and Romanesque mosaic patchwork; on the pattern, it is in Islamic geometrical structure and Berber star; historically, it was brought in Morocco by the Muslims from Spain; on the usage, it appears in Moroccan structure with traces of Spanish Muslims, etc. The Moroccan ceramic mosaic is a diverse information combination of ceramics in material, mosaic patchwork in European style and Islamized geometrical decorative functions.

Compared with the quadrel drawing and tiling in typical Islamic architectures, it seems that Zellige belongs to Islamic culture. However, seen from the size and arrangement style, it is obviously closer to the mosaic in Mediterranean cultural circle. But, seen from the mosaic itself, Zellige is the product of Islamic culture, because its strict geometrical pattern and continuous structure have nothing to do with the Romanesque mosaic images composed by the curves. It is at first fired into low-fired porcelain pieces. Then, they are chiseled into smaller pieces manually according to the demand. Finally, they are tiled on the floors and walls as the specifically designed geometrical patterns arrangements and compositions. Later, in Tetuan, the design is cut on the slabs first, then glazed and burnt. The new approach replaced Fiss approach to burn first and chisel later. The glaze composition of tiled Zellige shines with metallic lustre under the sunshine. Combined with continuous geometric patterns and colors, the Zellige forms the main visual characteristics of Moroccan Islamic architectures. Zellige is adopted almost in all the traditional Arabian architectures in Morocco to decorate the floors and walls in the courtyards.

\section{MiXed SPATIAL ART-ROMANESQUE MUSLIMS}

\section{A. The Formation of Maghrib Architecture Style}

Morocco is located in the northwest of the North Africa. Its shortest distance from Spain is only tens of kilometers. However, these tens of kilometers not only represent the distance between two continents, but also constitute a fuzzy region of our classification on Moroccan culture. It mixed Asian, European and African cultures. It also mixed the Islamic and Christian cultures. In the past, Morocco belonged to Maghreb Empire. According to numerous writing materials, the empire included Morocco, Algeria, Tunisia and the Iberian Peninsula which is a part of Spain now. The empire existed from 8 th century to 16 th century, for almost one thousand years. It is hard to tell the peak of one civilization and its influence. The peak of Maghreb is during the Aghlabids Dynasty in 9th century which menaced the Rome with Phrygian army and dominated the Mediterranean or during the 
Almohades era from 1147 to 1269 when Maghreb was really governed by the Berbers for the first time and the empire included a large area from Tripoli to Seville? We have to admit that there were many peaks during its history. The Almohades Dynasty overthrew the Almoravdes Dynasty, but they belonged to the same era culturally from 1061 to 1269 . Except in the religious aspect, $M$. Talbi affirms that there is no cultural break during the dynasties; particularly, Almohades art was introduced from Spain and developed into maturity during Almoravdes Dynasty. ${ }^{1}$

First, we should realize that there are two different kinds of architecture styles in Morroco: Berber style and Arabian style. Berber architectures are mainly distributed in the Atlas Mountains or the area more southerly. This is an area with long history. There seems to be no any change since remote antiquity. Ancient Maghreb governor, the Frenchman Henry Campbell, mentioned that the king of the kingdom is an architecture nut. Abd al-Mu'min, the founding king of Almohades, established the Koutoubia Tower in Marrakech. His son, Abu J. Yusuf, established the Grand Mosque and the Giralda Tower. Mansour established the Rabat city wall with splendid gates and started the project of the Hassan Tower, etc. Andalusia focuses more on delicacy rather than majesty. In the 14th century, the Moors flowed back to Africa from Spain and started many studios. From then on, the arts in Fiss and Granada are no more identical. ${ }^{2}$

The Marrakech and the Taggart Palace established by Almoravdes were ruined already in the war and disappeared as the time passes by. Even the existing Karaouiyne Mosque in Fiss established during Merinid Dynasty in 13th century is based on the architectures in the middle of the 9th century. With both length and width of 60 meters, it combines the majesty of the Sahara and the elegance of Andalusia. It is worth mentioning that the Karaouiyne Mosque in Fiss is the proof for the earliest Zellige in Morocco. Moreover, Zellige also remains in the ruins of the Palais Bahia in Marrakech in the 14th century. G Marcais writes: "we do not have to highlight the significance of the Grand Mosque; its design is special, the fusion of the roof in prismatic roundness in Andalusia style and corbel convex of Iranian Mukarnas style. It owns a high position among the Muslim architectures. 4" It represents the artistic peak of the western Muslim world. Later, the empire was divided into four independent kingdoms: one in Spain and the other three in Maghreb on which Morocco, Algeria and Tunisia are based.

M. Talbi mentioned in "The Maghreb Culture Communication and its Influence on Western Civilization" that finally, it worth mentioning that in Almohades art, grandeur is set off with lively decorations and rainbow colors and Zallidj is adopted particularly. ${ }^{3}$ This is a dispute on the appearance of Zellige, because the earliest existing Zellige is in the mosque in Fiss which was established during Marin Dynasty in 1269. As the logic of Talbi, the existing Zellige is a mature and forceful and lofty art. Thus, the appearance of Zellige must be earlier than this period. However, the archaeologists who pay more attention to the evidence do not agree. They think that the Europeanized Islamic art brought by the Spanish Muslim immigrants in Morocco during Marin dynasty just developed in Morocco. The representative of this opinion is Boogie, the art historian of Tetuan.

Under this background, Zellige appeared. It is not so close to the typical Islamic tile design in Isnik in Turkey but close to the Mosaic in ancient Rome. First, it is demanded by the architectures. A large number of Spanish Muslim artisans escaped in North Africa, in Morocco mainly. They would surely bring their architecture and decoration styles. We can find it out just by a look at the ruins of Medersa, a new-style architecture in 13th century. Isabelle from the UK, the author of "The History of Islamic Culture", also noticed the features of these special architectures of mixed cultures, for which she visited and researched a building in Tetuan 150 years ago. This building, a higher education institute of western Islamic style, which was established by Marin Dynasty, had a very clear design. Nowadays, it is a main example of the space application of the Zellige. It also influenced largely the architecture structure and style of Medina: Zellige fountain as the center of the courtyard in the middle of the building and the courtyard surrounded by the opened big rooms with the floors and walls tiled with Zellige. There are channels connected to the students' dormitories around the buildings with two or three floors surrounding the inner courtyard. This kind of Medersa turns into the main model of the Raid in Morocco. Tiled with Zellige on the wall and the floor, it is a special Maghreb venue combining the religious meeting and the altar of the buried saints. Zellige is a necessary part of the building. Though based on Roman mosaic, Zellige does not adopt its image and material any more. Finally, it finished the transformation from the visual image of fixed view to visual structure of nomadic view with restraint, profound, precise and abstract geometrical structure as well as some controllable hues of moral and religious doctrines.

\section{B. Geometrical Aesthetic Logic}

Almost all the civilizations have ever talked about geometry and symmetry. But they get truly prosperous in Islamic civilization. Zaid J. Abbass believes that this kind of art reached its peak in the middle of the 14th century when some splendid architecture appeared like Alhambra in Nasrid Dynasty in Spain. Except the architectural structure, it is the Zellige giving full play to the "well-balanced script" proposed by Ibn Mugla that constitutes this building. Zaid J. Abbass wrote sadly:" Because of the decline of Islamic civilization and research, this exploration on geometry has lost its vitality and then fell into silence, though in some areas like Morocco particularly, these ancient skills still prevail."5

Numerous geometrical design models appear in Islamic culture. These designs can be found in many objects in different materials and shapes: ceramic tiles, brick walls, woods, brass, papers, plasters and glasses. They may also appear on the blankets, manuscripts and wooden carving products, especially on the doors, screens and pulpits. They are more obvious on the surface of the architecture. ${ }^{5}$ The formation of the interweaving line elements of the image models presents the origin and experience of the Muslim tents and blankets. That "Interweaving is all" presents the feature of another kind of Islamic designs, a repeating feature associated with mobility and infinity. Repeated use of grids is the 
geometrical basis of Islamic design models. This feature can be reflected clearly on the repetition of the grids of the ceramic mosaics. The endless repetition of the grids fills the space to the largest extent. Thus, geometry is neuter. That is why we have to prove the decorative appearance of the Maghreb buildings and other artworks from the 10th to the 16th century to define the Moroccan Islamic geometrical patterns. From this point, we can conclude the features of the Zellige geometrical patterns: basically star shape, the overlap and repetition of grids and rounds, symmetry and copies, etc.

The mixed geometrical patterns form thousands of pattern groups. In the rich and delicate Zellige pattern models of the Alhambra, eleven different types of groups were found at first, which attracted the attention of the scholars. In 1980's, R. Gomez from Granada University and J. Montesinos from Madrid University found even 17 pattern groups.

\section{Zellige - MoroccAn Ceramic MosAic OF MiXeD Cultural LANGUAGE}

\section{A. Geometry and Continuity of Zellige}

Different from Chinese art which focuses by the eyes and expresses through visual images, Islamic culture express its art through continuous geometry but not breaks. On the one hand, it is because the Islam forbids image description which would mislead the eyes. The deeper reason lies on the fact that Muslim translated numerous ancient Greek and Roman literatures on philosophy and math at the formation of Islam. Based on these translation works, Muslims realized that the visual mission lies not only on the depiction of the visual image, but also on seeing the form of goodness more easily. In this case, besides spread easier and more effective, geometry can also bring psychological pleasure on psychological and aesthetic level. No any image of the people or animals is one of the most obvious features of Islamic artistic culture. Even the plants all over Islamic artistic languages appear mainly implicitly in geometrized plant structure and are rarely highlighted alone realistically. There are religious reasons for this phenomenon. On one hand, Islamic philosophers realized faintly that the worship to the image might cause misleading; different skills or other hidden information might cause ambiguities and these ambiguities might be strengthened for these concrete images. On the other hand, the saints really realized that the visible images were just fixed illusions, while the structure and the invisible inherence was the true essence of the Islam. Moreover, because of the natural connection between early Islamic culture and nomadic culture, compared with the image in a fixed place from a fixed point of view, the mobile and stable decorative structures influence obviously more largely nomadic architecture space and clothes. Moreover, the calculable mathematical and geometrical aesthetics in geometrical patterns can realize the transmission with minimum errors and be distributed to everyone precisely in practical operation. This is an objective aesthetics completely different from subjective experience. As the passed Islamic saints said, the dominance of geometry is ultimate; the universal harmony can only be realized through the purest geometrical forms. ${ }^{5}$ This trend of everything can also drive the thinking to approach with all effort the ultimate happiness. In the 10th century, the Maghreb geometrician, Ibn Ibn Mugla, benefit from the contact with Muslim intellectuals and Greek science and thinking, proposed the theory of "well-balanced script", which turns into the core of the visual harmony of Islamic art and architecture. It also sows the seeds for the Arabian letters and the geometrical process in the space as well as the appearance of Moroccan ceramic mosaic, Zellige. It provides a visual association and a proportional measurement for this aesthetic value.

\section{B. Technical Cause of Zellige}

Zellige combines the Roman mosaic work, Islamic architectural tiling and the application of the comparison of blue and green. During the Marin Dynasty in the 13th century, Zellige is influenced by the mosaic mural in Spanish Andalusia period. Later, Islamic culture entered Spain then was driven out of Spain gradually. Zellige started to be produced in the 13th century in Fiss and Marrakech in Morocco and reached its cultural peak in the 14th century. During nearly 800 years from 711 to 1492 , with the conflict and communication between Islamic and Christian cultures, experiencing ups and downs in the south of Spain, the Maghreb Zellige art which mixed Moorish and Islamic cultures took shape gradually around Mediterranean, especially in Morocco and Spain. That is the Moroccan ceramic mosaic style nowadays. Zellige art which mixed Andalusia, Islamic and Berber cultures started to flourish and well developed in Nasir Dynasty and Merinides Dynasty. In 14 th century, it was paid more attention. Blue, green and yellow were introduced based on white and black. In 17th century, red was added in Zellige in Fiss. Traditional colors increased to six from five. Zellige got into mature peiod in Fiss in 15 th century and spread in the whole Morocco. Finally a more precise production method of Zellige appeared in Tetuan. The pottery clay will turn read after burning for its higher ferric content, while the clay in Fiss is white grey, Thus, Zellige in Tetuan have been keeping its five traditional colors. However, the red color appeared gradually because of the wear of long time use. The red color goes very well with other colors. Thus, after hundreds of years, Zellige in Tetuan looks more beautiful. Compared with stone material, the colors of the ceramics fired with low-temperature wood, easier processing and splicing make Zellige the most splendid artistic mode in Islamic architecture. This aesthetic style got into shape and replaced the previous Mediterranean mosaic. Finally, it turned into a specific Islamic design and an artistic form with aesthetic object.

In ceramic producing area, such as Tetuan, Safi and Charey, except kaolinite, illite and chlorite, there are also traces of montmorillonite, chlorite mixed layer and illite in clay mineral. The Tetuan clay is illite clay. It includes illite (54-61\%), kaolinite $(11 \%)$, montmorillonite $(8 \%)$, chlorite $(6-19 \%)$ and terra rossa $(10 \%)$. The composition of Fiss clay is more balanced. The contents of illite (40-48\%) and kaolinite (18$28 \%$ ) are the highest in it, $70 \%$ in total together. There are also a little Chlorite (12-15\%) and smectite (9-12\%) in the clay normally. Moreover, the trace of mixed layer of illite and chlorite also exist in the clay we collected and researched. 


\section{CONCLUSION}

Zellige is a neuter geometrical material art in combination with Mediterranean and Islamic cultures. It is also the essence of the civilization. Beside the Mediterranean and under the blue sky, with incessant chanting in the mosques, Zellige is shining everywhere we can see and reminding us of the attention to art and religion. The reason why Zellige is often ignored in the history of the art lies on two points. On the one hand, it cannot be classified. As mentioned above, it has Islamic image, Meditteranean body and geometrical calculation, etc. On the other hand, the point of Zellige is even not ceramics and ceramic firing, but long-time training on calculation and Islamic geometrical pattern. The most important for this kind of art is neither how to produce nor subjective imaging, but an embedded geometrical and mathematical understanding approach. When we find this, we can understand the difficulty in classification.

\section{REFERENCES}

[1] Zebo, African Hisotry Volume 4 \& 5. 《非洲通史 第四卷, 第五卷》 泽博等主编

[2] Henry Campbell, Moroccan History, Shanghai People's Publishing House, 1975. 《摩洛哥史》 法国 亨利. 康崩上海人民出版社 1975

[3] Ni Ang, African Hisotry Volume 5. 《非洲通史第五卷》尼昂主编

[4] Achmad Yuusuf Hassan, translated by Liang Bo \& Fu Yingda, Brief Hisotry of Islamic Technology, 2010, Science Press; 《伊斯兰技术简 史》叙 艾哈迈德. 优素福. 哈桑梁波 傅颖达译 2010 科学出版社

[5] Abbas \& Salman, translated by Cui Zhongzhou, Symmetry of Islamic Geometrical Mode, Ningxia People's Publishing House, 2016; 《伊斯 兰几何模式的对称》 英国 阿巴斯, 萨勒曼著, 崔忠州等译 宁夏人 民出版社 2016

[6] Gonon \& Utokin, translated by Translation Group of Geographic Department in Northwest University, Morocco: Introduction to Natural Geography and Economic Geography. 1977, Shaannxi People's Publishing House 《摩洛哥 自然地理和经济地理概要》 前苏联 高 农 乌脱金 西北大学地理系翻译组 1977 陕西人民出版社 